\title{
THE POST-NATAL DEVELOPMENT OF THE REPRODUCTIVE TRACT OF THE SUFFOLK RAM, AND CHANGES IN THE GONADOTROPHIN CONTENT OF THE PITUITARY
}

\author{
J. D. SKINNER, $\uparrow$ W. D. BOOTH, L. E. A. ROWSON AND \\ H. KARG* \\ A.R.C. Unit of Reproductive Physiology and Biochemistry, $\$$ \\ University of Cambridge, and \\ *Institute of Animal Physiology, University of Munich
}

(Received 1st December 1967)

\begin{abstract}
Summary. The growth of the pituitary and of the reproductive tract of Suffolk rams from birth to 168 days of age has been studied. Pituitary ICSH and FSH concentrations were determined by bio-assay. The pattern of testicular androgen production has been examined using chemical and histological techniques and the relationship to spermatogenesis studied. Pituitary gonadotrophin content increased sharply from 42 days of age but was only weakly correlated with other parameters measured. The androstenedione : testosterone ratio was at its narrowest at birth; however, testosterone was the predominant androgen from birth onwards. Androgen concentration fluctuated but the total content increased with increase in testicular weight. Fructose was present in the seminal vesicles from birth and citric acid from 14 days; citric acid concentration was about one-tenth that of fructose. There was a significant correlation between testicular androgen content and the fructose and citric acid concentration and content of the seminal vesicles. Seminiferous tubule diameter was significantly correlated with most of the parameters measured. Testicular weight increased sharply from 42 days of age. Androgen production was present at birth and preceded spermatogenesis which began when testis weight exceeded $10 \mathrm{~g}$, which was after 56 days of age. Spermatozoa were present in the seminiferous tubules at 112 days of age.
\end{abstract}

\section{INTRODUCTION}

Some aspects of sexual development in the ram foetus have been studied previously. For example, Baillie (1960) studied the testicular interstitium and the origin of ovine Leydig cells and Aitken (1959) the histological

$\dagger$ Present address: Research Institute for Animal and Dairy Science, Private Bag, Irene, Transvaal, Republic of South Africa.

$\ddagger$ Postal address: Animal Research Station, 307 Huntingdon Road, Cambridge. 
development of the seminal vesicles, prostate and bulbo-urethral gland, which in the late-term foetus resemble those in the castrated adult.

The object of the present study was to examine the sexual development of the Suffolk ram from birth to 168 days of age.

\section{MATERIALS AND METHODS}

Material was provided by fifty-four Suffolk lambs allocated at random into six groups for slaughter at intervals of 14 days, from birth to 168 days. To obtain sufficient material for assay the numbers in the groups were as follows: ten at birth, eight at 14 days, six at 28 days, four from 42 to 70 days, two from 84 to 154 days, and six at 168 days. Histological observations on the testes of a 103-day-old ram foetus and a 105-day-old ram have also been included.

The lambs were weighed before slaughter, after which the head was immediately removed, the pituitary gland removed, weighed, sealed in tin foil and frozen over solid $\mathrm{CO}_{2}$ within 3 min of slaughter.

The testes were then removed, weighed and slices taken for histology, the testes were then stored over solid $\mathrm{CO}_{2}$. The amount of testosterone and androstenedione in the testes was estimated later. The remainder of the tract was dissected out, the accessory glands weighed individually, slices taken for histology and the seminal vesicles then stored over solid $\mathrm{CO}_{2}$. The amount of seminal fructose and citric acid was estimated later.

\section{ICSH and FSH pituitary bio-assay procedures}

Frozen pituitary glands were despatched by air to Munich where they were assayed for gonadotrophins by Professor Karg in his laboratories. The interstitial-cell stimulating hormone (ICSH) determinations were carried out by the ascorbic-acid-depletion test as summarized by Brüggemann, Adam \& Karg (1965) according to the method of Karg (1957) and Parlow (1958, 1961). The follicle stimulating hormone (FSH) assay was the augmentation test after Steelman \& Pohley (1953), with the modification using haemin as adjuvant, according to Labhsetwar, Collins, Tyler \& Casida (1964). The standard preparations used in the test were NIH-LH-B3 for ICSH and NIH-FSH-s3 for FSH, supplied by N.I.H., Bethesda, U.S.A.

\section{Testosterone and androstenedione assay}

Testosterone and androstenedione determinations were carried out according to the method described by Mann, Rowson, Short \& Skinner (1967) with certain modifications. A large amount of tissue was required as it was apparent from Lindner's (1960, 1961, 1963) determinations that only small amounts of androgen were present in and secreted by the ram's testis. A method was therefore developed for determining the androgen concentration in up to $50 \mathrm{~g}$ of testicular tissue. The tissue was homogenized together with $0.05 \mu \mathrm{c}$ each of tritiated testosterone and androstenedione in $100 \mathrm{ml} 2.5 \%(\mathrm{w} / \mathrm{v}) \mathrm{NaOH}$ and the homogenate was extracted first with $600 \mathrm{ml}$ of ether and then re-extracted with a further $200 \mathrm{ml}$. From then on the steps were essentially similar to those described by Mann et al. (1967) except that the pooled methanolic extracts 
were evaporated to dryness and preliminarily chromatographed using thin-layer chromatography, medium Silica-gel GF 254 and solvent system $\mathrm{CHCl}_{3}$ :EtoAc $(2: 1)$. This step finally removed contaminating substances which would otherwise have interfered with the resolution of the paper chromatography steps.

Fructose and citric acid assay of the seminal vesicles

These were analysed for fructose and citric acid as described by Lindner \& Mann (1960). Preliminary observations showed different concentrations of fructose and citric acid from different areas in the ram's seminal vesicle and the whole gland in the lamb was therefore cut into small pieces while still frozen, thoroughly mixed and a random sample taken.

\section{Histochemical and histological techniques}

Pieces of testes were fixed in Bouin's fluid or Zenker-formol solution. Pieces of seminal vesicles, ampullae and bulbo-urethral glands were fixed in Bouin's fluid. The Bouin-fixed material was dehydrated in alcohol, cleared in cedarwood oil and embedded in paraffin wax; sections, $6 \mu$ thick, were stained with Delafield's haematoxylin and chromotrope 2R. The Zenker-formol fixed tissue was postchromed in potassium dichromate, washed, dehydrated, cleared, embedded in paraffin wax, sectioned and treated with Sudan black as described by Threadgold (1957) in his Method 1.

Further slices of testis were frozen on to cryostat chucks with the aid of solid $\mathrm{CO}_{2}$ and sections cut $16 \mu$ thick, incubated for 3 or $4 \mathrm{hr}$ at $37^{\circ} \mathrm{C}$ to demonstrate the presence of $\Delta^{5}-3 \beta$-hydroxysteroid dehydrogenase activity as described by Hay \& Deane (1966) and Mann et al. (1967).

Seminiferous tubule diameter was the mean calculated from twenty-five circular tubules measured in cross-section.

\section{Statistical analysis}

To obtain correlation and regression coefficients between various parameters the material was divided into two groups according to seminiferous tubule development and within group coefficients calculated. The first group comprised those in which spermatogenesis had not yet commenced and included all testes of $10 \mathrm{~g}$ or less and all animals up to 42 days of age. In the remainder of the lambs which were 56 days and over, testis weight was increasing more rapidly, exceeding $10 \mathrm{~g}$, and it appeared from calculations based on the time spermatozoa appeared and the length of the spermatogenetic cycle, that spermatogenesis was about to commence.

\section{Weights}

\section{RESULTS}

Body weight increased sharply from birth to 70 days of age (when the average daily weight gain was $457 \mathrm{~g} /$ day) and more gradually from 70 days onwards at a rate of $143 \mathrm{~g} /$ day. The pituitary gland increased rapidly in weight from birth when it weighed $0.25 \mathrm{~g}$ to 98 days when it weighed $0.70 \mathrm{~g}$ after which 
there was no further increase in weight. There was a proportional increase in the weight of the anterior pituitary from $0.19 \mathrm{~g}$ at birth to $0.42 \mathrm{~g}$ at 98 days. Anterior pituitary weight was in fact highly correlated with pituitary weight (correlation coefficient $0.67, P<0.001$ ).

As can be seen from Text-fig. 2 the weight of the testes increased gradually from birth to 42 days of age after which there was a steep rise in growth rate. Seminiferous tubule diameter showed a similar increase, increasing gradually from $40 \mu$ at birth to $60 \mu$ at 56 days and $185 \mu$ at 112 days after which increase in diameter was very small and only measured $190 \mu$ at 168 days. The weights
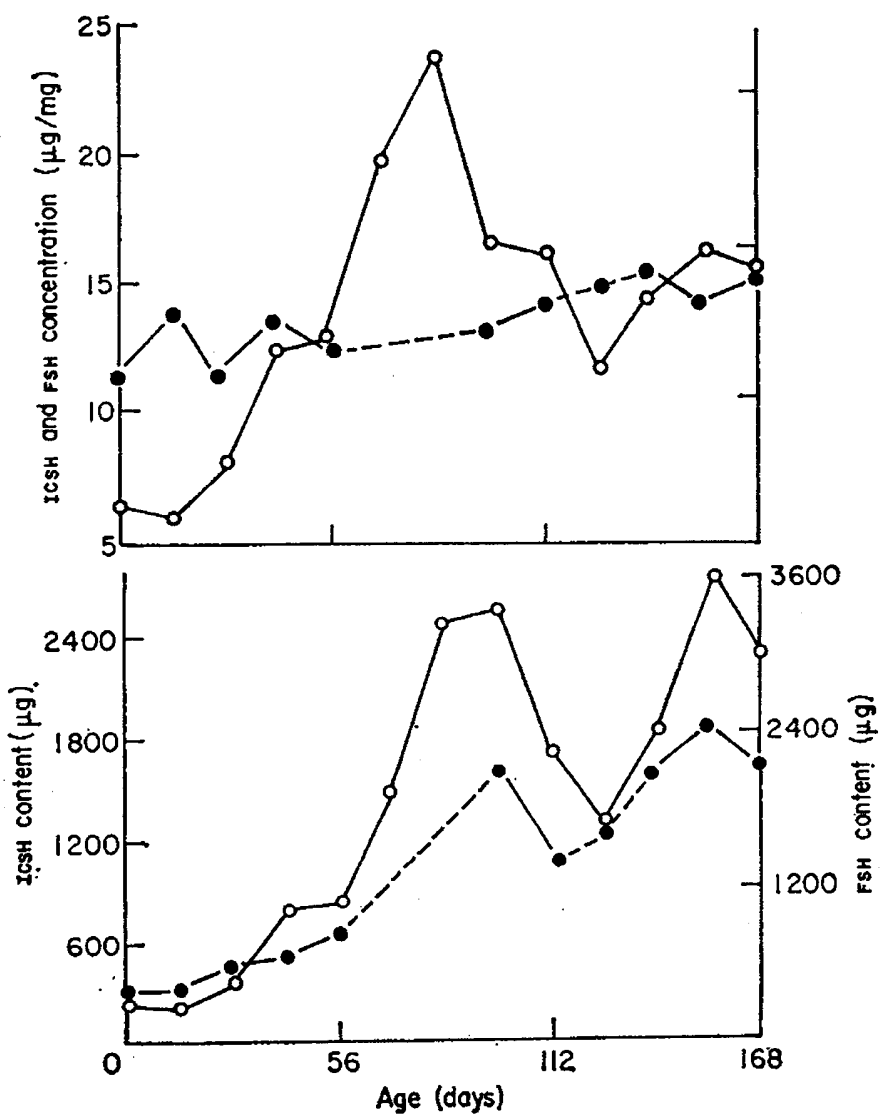

TEXT-FIG. 1. ICSH $(O)$ and FSH (O) concentration and content in the pituitary glands from developing Suffolk rams. Where insufficient material was available to give comparable results, broken lines have been drawn in.

of the accessory glands showed an increase with age similar to that of the testes, increasing more rapidly from 42 days of age. An example is the increase in weight of the seminal vesicles shown in Text-fig. 3 . The epididymides increased sharply at 112 days of age when spermatozoa started passing through the vasa efferentia.

Bio-assay of pituitary gonadotrophin

At the commencement of this study it was decided that in the event of 
insufficient material for the bio-assay of both ICSH and FSH, ICSH would receive priority. The FSH assays, although incomplete, are included as they represent the only material from pubescent rams yet available. The mean ICSH and FSH concentrations and contents of the pituitary glands at each age are graphically

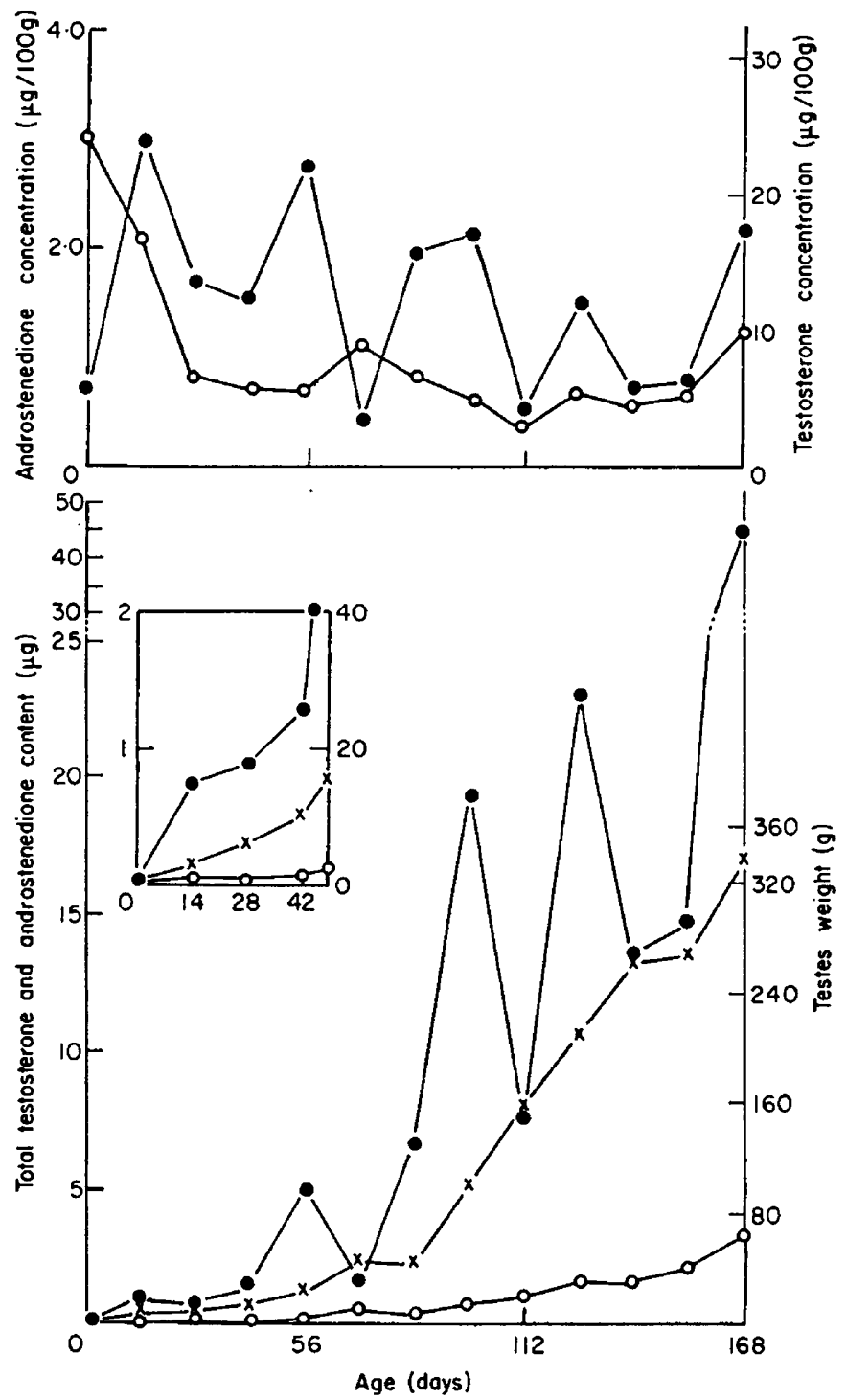

TEXT-FIG. 2. Testicular weight $(X)$, testosterone $(\bullet)$ and androstenedione $(0)$ concentration and content in Suffolk ram lambs. Inset, parameters magnified five-fold from birth to 49 days of age.

illustrated in Text-fig. 1. Where FSH assays were incomplete, the points have been joined by broken lines. It can be seen that ICSH concentration at first declines before increasing steadily to 84 days of age, after which there is considerable variation. On the other hand, FSH concentration increases only gradually from birth to 168 days of age. In the developing lamb, the pituitary 
is increasing in size and presumably in amount of secretory tissue. It would, therefore, seem better to express gonadotrophins in terms of total contents in addition to giving the concentration.

\section{Assay of testicular androgens}

The mean testosterone and androstenedione concentration and content in the testes at different ages are graphically illustrated in Text-fig. 2. Up to the age of 56 days an estimate from pooled material was obtained, after which individual estimations were determined, and the mean taken. It can be seen

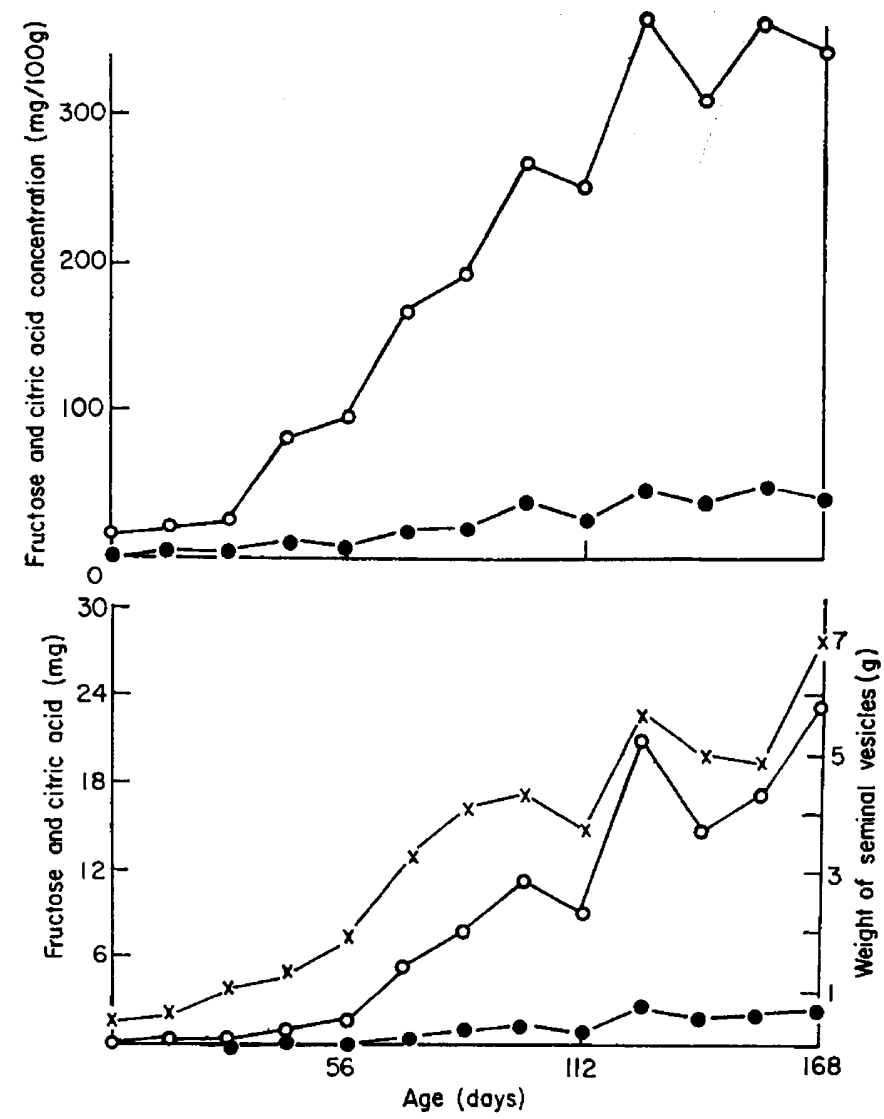

Text-Fig. 3. Seminal vesicle weight $(x)$, fructose $(0)$ and citric acid $(\bullet)$ concentration and content in Suffolk ram lambs.

that the concentration of testosterone reveals a random picture with fluctuations in the steroid titres from 4 to $24 \mu \mathrm{g} / 100 \mathrm{~g}$. This suggests a maximum production of testosterone during the growth period. The total amount of testosterone increased steadily with increase in testicular weight, again indicating the importance of expressing results as total contents where there is variation in organ size. Androstenedione concentration decreased steadily during the first 56 days of life. This may possibly imply that there is no exclusive metabolic relationship between the two steroids in the testis. The ratio of androstenedione 
to testosterone varied considerably from $1 / 1.75$ at birth to $1 / 13.83$ at 168 days and testosterone was always the dominant steroid. There was considerable variation in the androgen concentration from the testes of different rams. For example, the mean concentration of androstenedione from six rams at 168 days of age was $1.24 \pm 0.62 \mu \mathrm{g} / 100 \mathrm{~g}$ (range 0.26 to 4.05 ) and that of testosterone was $17.45 \pm 7.57 \mu \mathrm{g} / 100 \mathrm{~g}$ (range 1.22 to 40.42 ). Androstenedione levels do not vary as much as testosterone levels which may be due to different releasing mechanisms operating on the two androgens. For example, androstenedione, acting as an intermediate compound for androgen synthesis, may be easily bound in the cellular compartments of the testis whereas testosterone may be preferentially released after synthesis.

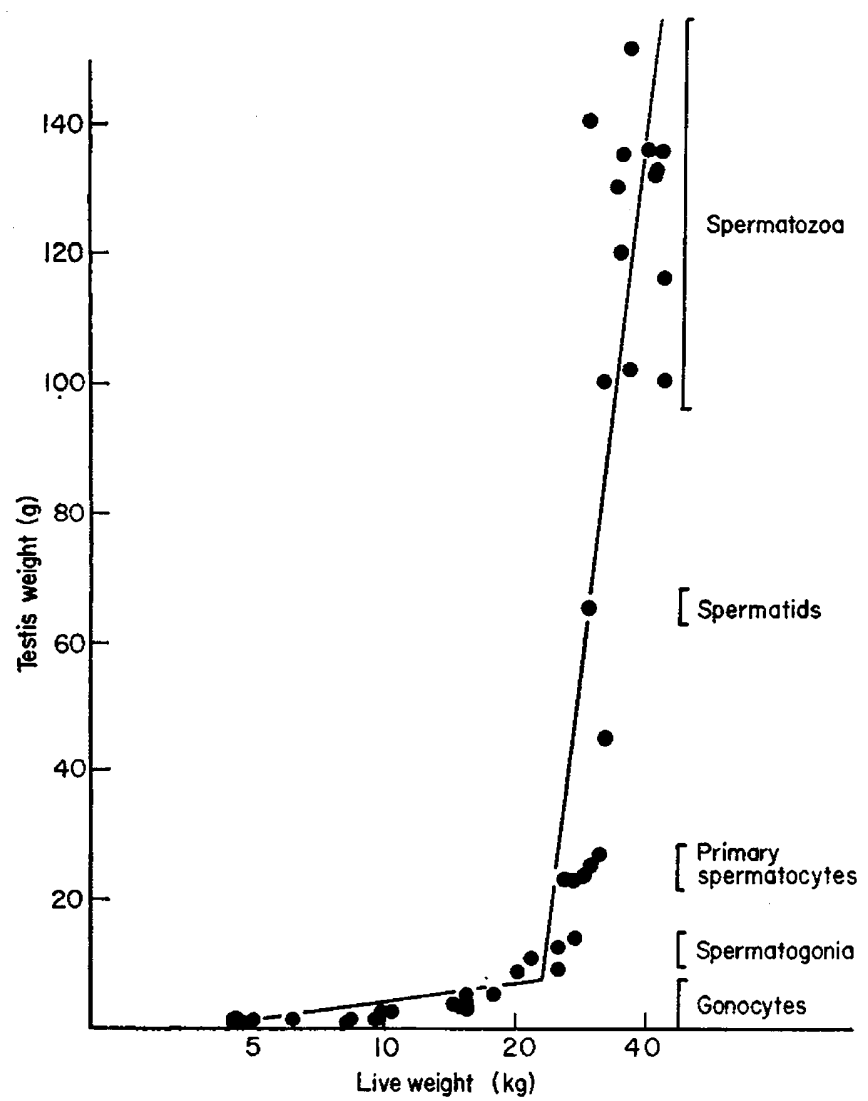

Text-rig. 4. Testis weight plotted against logarithm of body weight to illustrate the two phases of testicular growth and the relative state of spermatogenesis.

Estimate of fructose and citric acid in the seminal vesicles

The mean fructose and citric acid concentrations and contents of the seminal vesicles are graphically illustrated in Text-fig. 3. Up to the age of 6 weeks an estimate from pooled material was obtained, after which individual estimates were determined and the mean calculated. Fructose was present in the seminal vesicles from birth and, although there was no citric acid detectable at birth, 
this was probably due to insufficient tissue for assay. The citric acid concentration of the seminal vesicles was usually about a tenth of that of fructose. Unlike some other parameters, both fructose and citric acid increased in concentration with advancing age. There was a linear relationship between the fructose and citric acid content of the seminal vesicles and the testosterone content of the testes. For every unit increase in fructose, testosterone content increased by $1.69 \pm 0.17 \mu \mathrm{g}$. Conversely, for each increase of $1 \mu \mathrm{g}$ in testosterone content fructose content increased by $0.202 \pm 0.020 \mathrm{mg}$ and citric acid by $0.025 \pm 0.007 \mathrm{mg}$, i.e. only a tenth of that of fructose.

\section{Statistical analysis}

Significant correlation coefficients before and after 42 days of age are shown in Tables 1 and 2. Some correlations could not be calculated before 42 days of age because of the use of pooled tissue for estimates. After 42 days of age ICSH content was significantly correlated with FSH content (coeff. 0.69 ), seminiferous tubule diameter (coeff. 0.42 ), testes weight (coeff. 0.44 ), seminal vesicle weight (coeff. 0.46), ampullae weight (coeff. 0.43) and bulbo-urethrals weight (coeff. 0.49 ). FSH concentration was only significantly correlated with testosterone concentration (coeff. 0.62 ) and testosterone content $(0.67)$, while FSH content was poorly correlated with all parameters measured. There was, however, insufficient data on FSH to form definite conclusions about poor correlations. Failure to obtain satisfactory correlations between gonadotrophin concentration or content of the pituitary glands and other paramaters may have resulted from a combination of two factors: (i) no measure of the relationship to secretion rate and (ii) time lag between secretion by the pituitary and response by the target organ.

The two androgens are significantly correlated and androgen content is significantly correlated with vesicular fructose and citric acid content. In the developing lamb, however, testicular androgen content alone would not accurately indicate the stage of development reached by the animal.

\section{Histology}

The interstitium. Using standard methods for demonstrating $\Delta^{5}-3 \beta$-hydroxysteroid dehydrogenase in animals (Maeir, 1965; Baillie, Ferguson \& Hart, 1966; Hay \& Deane, 1966) it proved impossible to demonstrate the presence of this enzyme in the developing ram testis.

\section{EXPLANATION OF PLATE 1}

Sections of testes from Suffolk lambs at different ages. Figs. 1, 3, 5 and 7 stained with Sudan black to show interstitial cells, $\times 246$. Figs. 2, 4, 6 and 8 stained with Delafield's haematoxylin and chromotrope 2 R. Figs. 2 and 4 , inset $\times 480$, Figs. 4,6 and $8 \times 300$.

Fics. 1 and 2. Testis of a 103-day-old foetus. Note the gonocytes and supporting cells in the seminiferous tubules of Fig. 2.

Figs. 3 and 4. Testis of a new-born lamb. Gonocytes and supporting cells are still evident (Fig. 4). Inset, a tubule of the same magnification as in Fig. 2 to illustrate that tubule diameter has not increased.

Figs. 5 and 6 . Testis of a 56-day-old lamb. Note the appearance of lipid within the seminiferous tubule (Fig. 5). The seminiferous tubules were larger (Fig. 6) but still quiescent.

Figs. 7 and 8. Testis of a 126-day-old lamb. Note the abundance of lipid within the seminiferous tubule (Fig. 7) and all the stages of spermatogenesis (Fig. 8). 


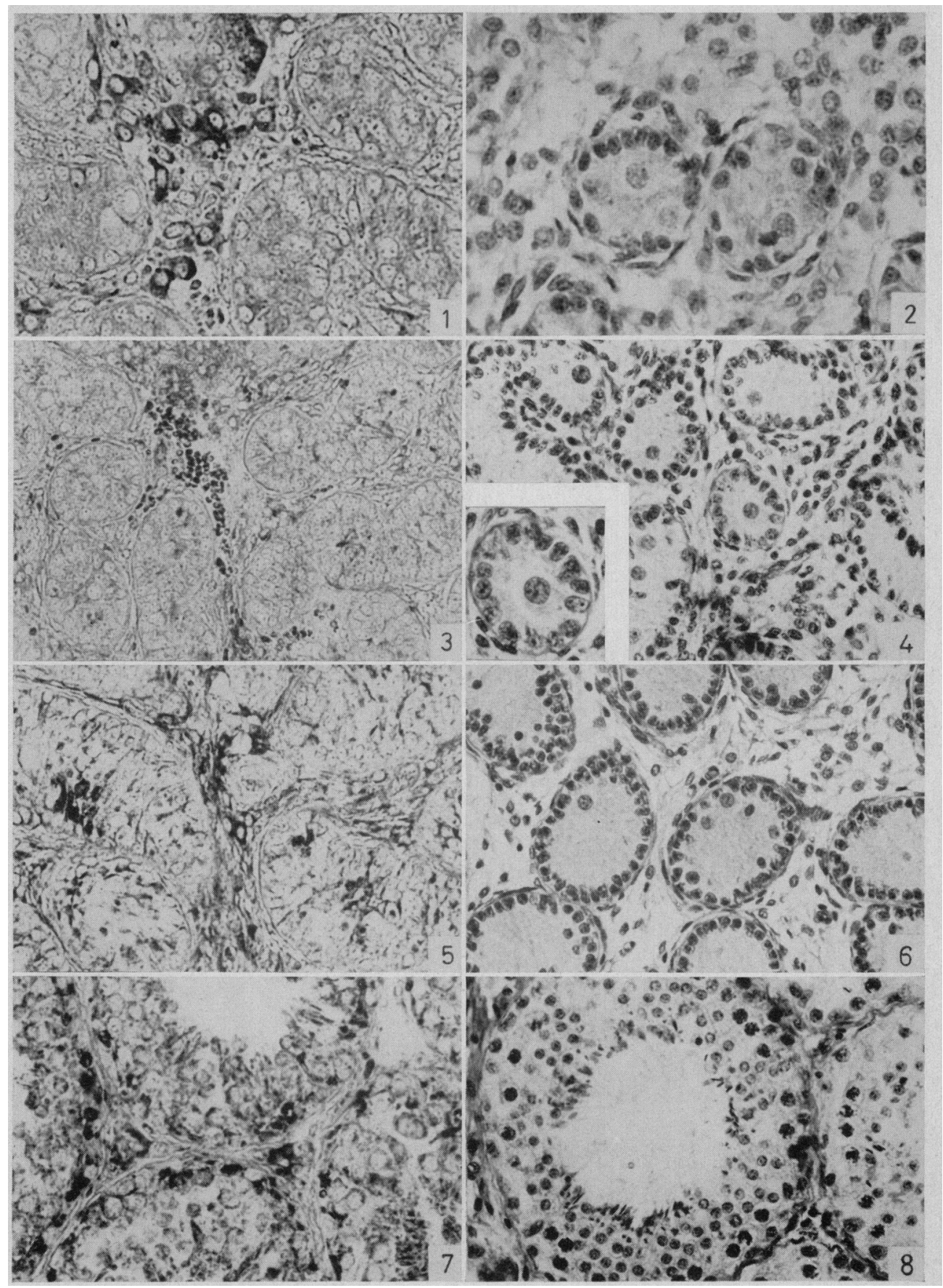

(Facing p. 470) 


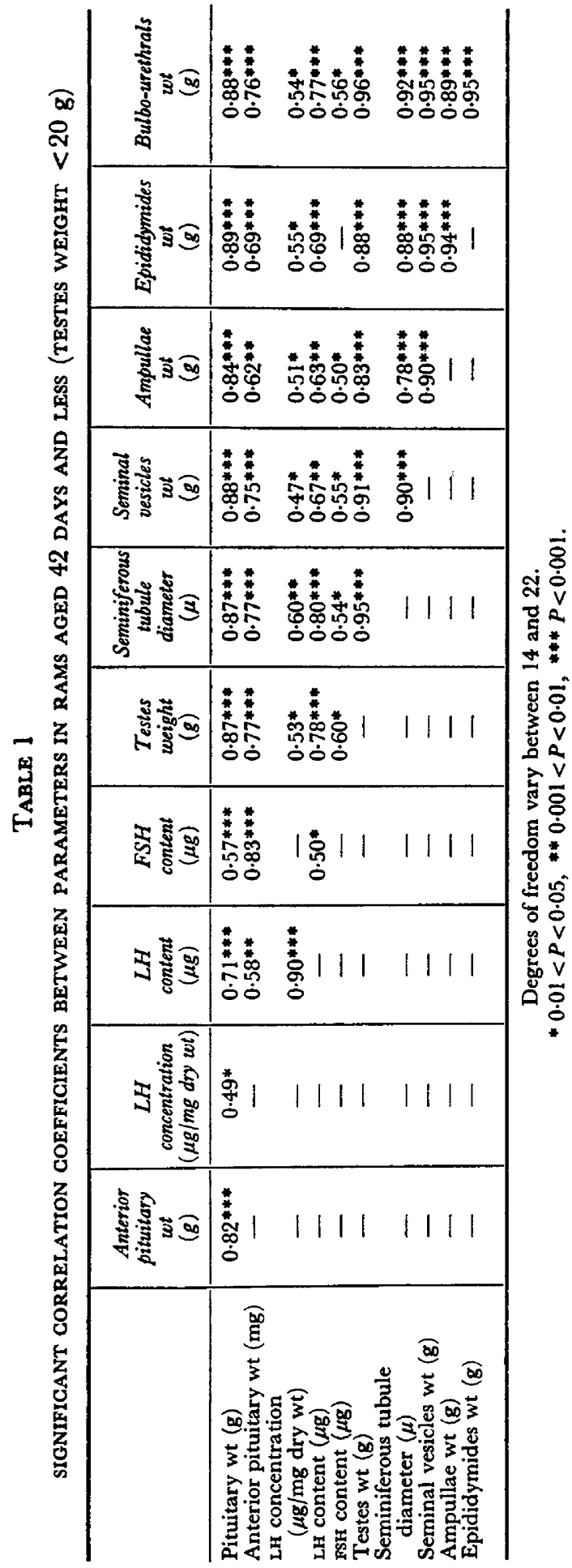


J. D. Skinner et al.

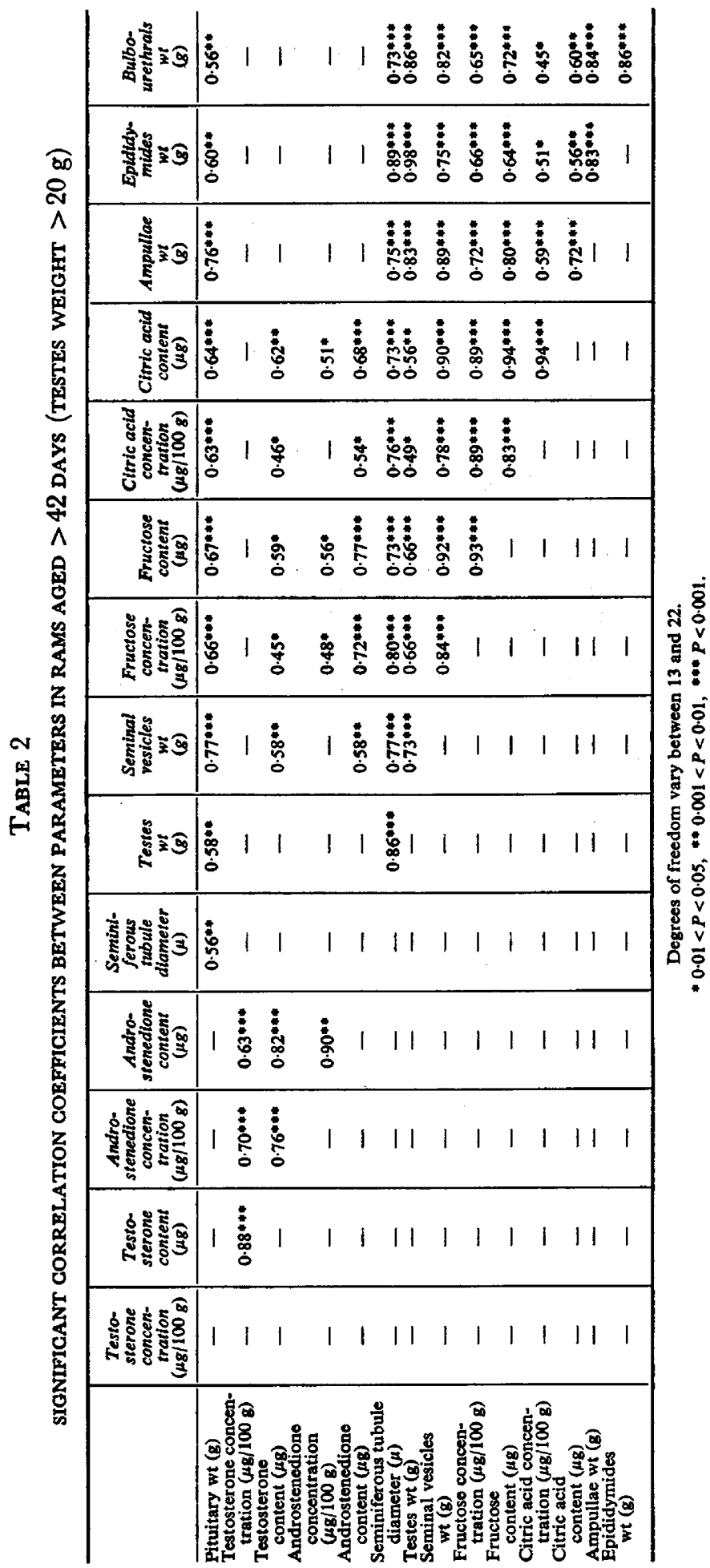


Using Threadgold's (1957) method for demonstrating lipids in the interstitium, deposits could be demonstrated in the foetal testis at 103 days and from birth onwards. Lipid was also apparent within the seminiferous tubules from 56 days of age. This is demonstrated in Plate 1, Figs. 1, 3, 5 and 7.

The seminiferous tubules. At birth, seminiferous tubules resembled those of a 103-day-old foetus and were the same size (Pl. 1, Figs. 2 and 4 and inset).

At 56 days of age, most seminiferous tubules still appeared quiescent in the majority of lambs with only gonocytes and supporting cells present (Pl. 1, Fig. 6). At 70 days, however, early primary spermatocytes had appeared. Late primary spermatocytes were evident at $\mathbf{8 4}$ days of age and in a single Suffolk lamb of 105 days, spermatids were much in evidence. Spermatozoa were present in the tubules at 112 days of age and a testis weight exceeding $100 \mathrm{~g}$.

Supporting cells had apparently differentiated into Sertoli cells at 70 days of age, coinciding with the onset of spermatogenesis.

TABLE 3

TIME OF APPEARANGE OF GERM CELLS IN DEVELOPING LAMB TESTES (DAYS)

\begin{tabular}{l|c|c|c|c|c}
\hline \multicolumn{1}{c|}{ Breed } & $\begin{array}{c}\text { Primary } \\
\text { spermatocytes }\end{array}$ & $\begin{array}{c}\text { Secondary } \\
\text { spermatocytes }\end{array}$ & Spermatids & Spermatozoa & \multicolumn{1}{c}{ Reference } \\
\hline $\begin{array}{l}\text { Southdown } \\
\text { Shropshire }\end{array}$ & 63 & 126 & 126 to 127 & 147 & $\begin{array}{c}147 \\
\text { Hampshire }\end{array}$ \\
$\begin{array}{l}\text { Merino } \\
\text { Ile de France } \\
\text { Suffolk }\end{array}$ & $\begin{array}{c}166 \\
70 \text { to } 84\end{array}$ & $\frac{70}{125}$ & $\begin{array}{c}120 \text { to } 125 \\
105\end{array}$ & $\begin{array}{l}126 \text { to } 182 \\
140 \text { to } 225 \\
112\end{array}$ & $\begin{array}{l}\text { Phillips \& Andrews (1936) } \\
\text { Carmon \& Green (1952) } \\
\text { Watson et al. (1956) } \\
\text { Courot (1958) } \\
\text { Present study }\end{array}$ \\
\hline
\end{tabular}

The different stages in spermatogenetic tubule development are illustrated in Plate 1, Fig. 8. The relationship of their appearance to testis weight is graphically illustrated in Text-fig. 4, and comparative figures from other workers presented in Table 3.

The seminal vesicles. The seminal vesicle of the developing lamb resembled that in the adult (Aitken, 1955) being a compound tubular gland in which individual lobules are separated by trabeculae of connective tissue and smooth muscle fibres. The secretory tubules are lined by a pseudostratified columnar epithelium of which the height varied from $27.0 \mu$ at birth to 19 to $25 \mu$ at 168 days of age. With increase in lumen size and 'stretching' of the lobules, secretory epithelial height could even decrease.

\section{DISCUSSION}

The growth of some British sheep breeds, including the Suffolk, has been described by Hammond (1932) in his classical monograph on the subject. In the present study, the rams increased rapidly in weight until 70 days of age, after which increases were more gradual. At 140 days, weights were very similar to those recorded by Hammond (1932). However, Hammond (1932) has emphasized the differences between the growth rate of lambs born in different years and a definite conclusion is, therefore, not possible on 1 year's 
observations. Testicular growth was similar in Suffolks to that in other breeds of sheep (Watson, Sapsford \& McCance, 1956; Courot, 1962).

The seminiferous tubule diameter similarly increased from birth in the Suffolk as in other sheep breeds (Phillips \& Andrews, 1936; Carmon \& Green, 1952; Courot, 1962). Changes in tubule diameter did not appear to be related to any particular stage in spermatogenesis.

Testosterone is the dominant testicular androgen from birth in the Suffolk ram, unlike the pubescent bull where this only happens at about 112 days of age (Lindner, 1959; Lindner \& Mann, 1960; Hay, Lindner \& Mann, 1961). Lindner (1961) suggested the relationship in the lamb may be similar to that in the bull, on the basis of a pooled estimate from three 35-day-old Welsh Mountain rams. The pooled sample contained $2.0 \mu \mathrm{g}$ testosterone and $2.4 \mu \mathrm{g}$ androstenedione per $100 \mathrm{~g}$ using the aqueous methanol extraction procedure. Pooled testes from four 28-day-old Suffolk lambs in this study yielded 13.76 $\mu \mathrm{g}$ testosterone and $0.81 \mu \mathrm{g}$ androstenedione per $100 \mathrm{~g}$. It is possible that these differences are genetic. However, Lindner (1961) experienced difficulty with the few androgen estimations he completed on the ram testis as he required a large amount of tissue to isolate one or two micrograms of steroid and did not have the advantages of thin-layer and gas chromatography. The ram testis has a high lipid content and using the aqueous methanol extraction procedure this lipid may have interfered with his testosterone recovery.

The sexual development of the lamb appears to be more advanced at birth than of the calf. For example, the penile sigmoid flexure is already developed in the 100-day-old lamb foetus whereas it was not present in newborn calves (Abdel-Raouf, 1960). Perhaps if a study on testicular androgens were extrapolated into foetal development a point might be reached where androstenedione is predominant. Certainly at birth the ratio of androstenedione to testosterone was at its lowest.

The significant correlations between testicular testosterone and vesicular fructose are in agreement with the results of Setchell, Waites \& Lindner (1965) who found a significant correlation between the testosterone secreted and fructose content of the seminal vesicles in the mature Merino ram. Moreover, while the present study was in progress Moule, Braden \& Mattner (1966) showed that the amount of fructose in the ejaculate of the castrate ram was linearly related to the dose of injected testosterone.

Seminiferous tubule diameter has already been recognized as an excellent parameter for measuring sexual function in the bull calf (Hay, Lindner \& Mann, 1961) and in the roe deer (Short \& Mann, 1966). However, tubule diameter was only poorly correlated with ICSH content, not at all with FSH, and there was no correlation with the androgens. Nevertheless, it was significantly correlated with every other parameter measured.

Hay \& Deane (1966) have implied that Leydig cells defy general definition, and vary from species to species. They mention that they are particularly difficult to identify in the ram and great difficulty was experienced in this study. Using DHA as the substrate, it was impossible to identify any $\Delta^{5}-3 \beta$-hydroxysteroid dehydrogenase activity in any of the lambs. This agrees with the findings of Baillie et al. (1966) in the mature ram. Hay \& Deane (1966) did demonstrate 
minute amounts in two out of ten rams, but emphasize that these results were atypical. However, using Threadgold's method for demonstrating lipids, it was possible to demonstrate lipids in the interstitium, which is in agreement with the results of Baillie (1960) in the foetus and Setchell et al. (1965) in the mature ram. In comparison with the bull, however, Leydig cells were very sparsely distributed. This is perhaps not surprising as the total testicular androgen in the 154-day-old lambs was, for example, only $16 \mu \mathrm{g}$ whereas Hay et al. (1961) found $711 \mu \mathrm{g}$ in the testes of a 148-day-old Friesian calf, that is nearly fifty times as much.

The time intervals between sighting the different cell types in the spermatogenetic chain are in broad agreement with the findings of Courot (1958). There were two major deficiencies in the present study; first, the time interval between the group autopsy was too great for this type of histological study, and second, different rams had to be killed at different stages. In addition, the number of lambs studied at each stage was too few. The time at which these cells appeared is, therefore, only approximate. The same criticisms could be levelled at most of the early studies, but that of Courot (1962) has been more thorough. Differences between these results and those published earlier may also be due to differences in defining cell types. Spermatogenesis in the Suffolk commences earlier than in other breeds studied. It starts when the testis exceeds $10 \mathrm{~g}$ in weight which is somewhat heavier than is the case in the Ile de France (Courot, 1962). Nevertheless, it follows a similar pattern, and is closely related to testis weight. It would appear, therefore, that spermatogenesis is more closely related to physiological age than to chronological age which agrees with previous results (Watson et al., 1956; Courot, 1962).

In view of Lacy's (1967) recently published hypothesis on the role of Sertoli cells, it is relevant to record that supporting cells appeared to have differentiated into Sertoli cells at 70 days of age, or slightly earlier. Lipid was apparent in cells along the basement membrane at this age, but as this was not in any way a similar histochemical study it is only possible to conclude that lipid may accumulate in these cells before any spermatozoa are shed into the tubule lumen. The pubescent male would appear most suitable for verifying Lacy's (1967) hypothesis.

In agreement with Aitken's (1955) observations, the secretory epithelial cells appeared to have an apocrine type secretion. Moreover, unlike the bull (Mann, Davies \& Humphrey, 1949), only A and B cells and no G cells were noted in the ram, again in agreement with Aitken's (1955) findings.

This study has shown that sexual development in the lamb proceeds at a slow rate from birth to 42 days of age, after which there is a characteristic rapid increase in all the parameters measured. This was apparently sigmoid in nature, although the study terminated before a definite plateau was reached. Of the parameters studied, seminal vesicle fructose and citric acid content accurately reflected the content of androgens in the testis and seminiferous tubule diameter appears to be of great value as a parameter in assessing sexual function.

It is apparent that, in the developing lamb, androgen secretion precedes spermatogenesis by several weeks, the latter beginning some time after 56 days 
of age. If an extrapolation is made from Ortavant's (1958) estimate of 49 days for the spermatogenetic cycle in the ram, then spermatogenesis starts at about 63 days of age in the Suffolk ram. Androgen secretion was small at birth but increased sharply from 42 days of age. This evidence that androgenesis precedes spermatogenesis has already been presented for the bull (Mann et al., 1949) and rabbit (Davies \& Mann, 1947; Skinner, 1967). There was no evidence to support the hypothesis advanced for the bull (Hay et al., 1961) that the appearance of spermatogonia coincides with the onset of the androgen-dependent secretory function in the seminal vesicles.

Puberty in the lamb was not characterized by any special relationship between the testicular androgens. The results of the present study favour the view that puberty occurs when the testes begin to show marked androgenic activity and the accessory glands begin to produce and secrete fructose and citric acid. This would coincide with the sharp increase in growth rate of the reproductive tract. Puberty is a phase in development in lambs and spermatozoa appear towards the end of this phase. It is that time when the secretion of androgen, in response to pituitary gonadotrophins, accelerates the development of their target organs and the secondary sexual characteristics develop.

The results of this study support the definitions of puberty of Marshall (1922) and Donovan \& Werff ten Bosch (1965).

\section{ACKNOWLEDGMENTS}

We would like to thank Dr H. M. Dott and Professor T. Mann for their interest in this work and for reading the manuscript, $\mathrm{Dr} \mathrm{R}$. V. Short for advice on the steroid assays and Dr Mary Hay for advice on the histology. One of us (J.D.S.) is indebted for a scholarship to British Petroleum (Southern Africa). The gonadotrophin studies were supported by the Deutsche Forschungsgemeinschaft.

\section{REFERENCES}

AbDel-Raour, M. (1960) The postnatal development of the reproductive organs in bulls with special reference to puberty. Acta endocr., Copenh., Suppl. 49, 1.

Artken, R. N. C. (1955) A histochemical study of the seminal vesicle of the sheep. F. Anat. 89, 430 .

Artken, R. N. C. (1959) Observations on the development of the seminal vesicles, prostate and bulbourethral glands in the ram. F. Anat. 93, 43.

Baillie, A. H. (1960) The interstitial cell in the testis of the foetal sheep. Q. $J l$ microsc. Sci. 101, 475.

Baillie, A. H., Ferguson, M. M. \& Hart, D. McK. (1966) Developments in steroid histochemistry. Academic Press, London.

Brüggemann, J., Adam, A. \& Karg, H. (1965) ICSH-Bestimmungen in Hypophysen von Rehböcken (Capreolus capreolus) und Hirschen (Cervus elaphus) unter Berücksichtigung des Saesoneinflusses. Acta endocr., Copenh. 48, 569.

Carmon, J. L. \& Green, W. W. (1952) Histological study of the development of the testis of the ram. 7. Anim. Sci. 11, 674.

Courot, M. (1958) Cited by Ortavant, R. (1959) In: Reproduction in domestic animals, Vol. 2, chap. 1. Eds. H. H. Cole and P. T. Cupps. Academic Press, London.

Courot, M. (1962) Developpement du testicule chez l'agneau. Etablissement de la spermatogénèse. Annls Biol. anim. Biochim. Biophys. 2, 25.

Davies, D. V. \& MANN, T. (1947) Functional development of accessory glands and spermatogenesis. Nature, Lond. 160, 295.

Donovan, B. T. \& WerfF ten Bosch J. J. van Der (1965) Physiology of puberty. Edward Arnold, London. Hammond, J. (1932) Growth and development of mutton qualities in the sheep. Oliver \& Boyd, Edinburgh. 
HAY, M.F. \& DeANE, H.W. (1966) Attempts to demonstrate $3 \beta$ - and $17 \beta$-hydroxysteroid dehydrogenase histochemically in the testes of the stallion, boar, ram and bull. $\mathcal{f}$. Reprod. Fert. 12, 551.

Hay, M. F., Lindner, H. R. \& ManN, T. (1961) Morphology of bull testes and seminal vesicles in relation to testicular androgens. Proc. $R$. Soc. B, 154, 433.

KARG, H. (1957) Ascorbinsäuredynamik im Ovar als Gonadotropinnachweis. Klin. Wschr. 35, 643.

Labhsetwar, A. P., Collins, W. E., Tyler, W. J. \& Casida, L. E. (1964) Effect of progesterone and oxytocin on the pituitary-ovarian relationship in heifers. J. Reprod. Fert. 8, 77.

LACY, D. (1967) The seminiferous tubule in mammals. Endeavour, 26, 101.

Lindner, H. R. (1959) Androgens in the bovine testis and spermatic vein blood. Nature, Lond. 183, 1605.

LiNDNER, H. R. (1960) Androgens in spermatic vein blood of farm animals. F. Endocr. 20, v.

LiNDNER, H. R. (1961) Testicular androgen in the ram, boar and stallion. f. Endocr. 23, 171.

Lindner, H. R. (1963) Partition of androgen between the lymph and venous blood of the testis of the ram. F. Endocr. 25, 483.

Lindner, H. R. \& MANN, T. (1960) Relationship between the content of androgenic steroids in the testes and the secretory activity of the seminal vesicles in the bull. 7. Endocr. 21, 341 .

MAEIR, D. M. (1965) Species variation in testicular $\Delta^{5}-3 \beta$-hydroxysteroid dehydrogenase activity. Endocrinology, 76, 463.

Mann, T., Davies, D. V. \& Humphrey, G. F. (1949) Fructose and citric acid assay in the secretions of the accessory glands of reproduction as indicator tests of male sex hormone activity. $\mathcal{J}$. Endocr. 6, 75.

Mann, T., Rowson, L. E. A., Shorr, R. V. \& Skinner, J. D. (1967) The relationship between nutrition and androgenic activity in pubescent twin calves, and the effect of orchitis. F. Endocr. 38, 455.

Marshall, F. H. A. (1922) The physiology of reproduction, 2nd edn. Longmans, Green, London.

Moule, G. R., BRADEN, A. W. H. \& MAtTner, P. E. (1966) Effects of season, nutrition and hormone treatment on the fructose content of ram semen. Aust. F. agric. Res. 17, 923.

Ortavant, R. (1958) Le cycle spermatogenetique chez le belier. D.Sc. thesis, Paris.

Parlow, A. E. (1958) A rapid bioassay method for LH and factors stimulating LH secretions. Fedn Proc. Fedn Am. Socs exp. Biol. 17, 402.

Parlow, A. E. (1961) Bio-assay of pituitary luteinizing hormone by depletion of ovarian ascorbic acid. In: Human Pituitary Gonadotropins. Ed. A. Albert. Thomas, Springfield, Ill.

PhILlirs, R. W. \& ANDrews, F. N. (1936) The development of the testes and scrotum of the ram, bull and boar. Bull. Mass. agric. Exp. Sin No. 331.

Setchell, B. P., Wartes, G. M. H. \& LindNeR, H. R. (1965) Effect of undernutrition on testicular blood flow and metabolism and the output of testosterone in the ram. F. Reprod. Fert. 9, 149.

Short, R. V. \& MANN, T. (1966) The sexual cycle of a seasonally breeding animal, the roebuck (Capreolus capreolus). F. Reprod. Fert. 12, 337.

Skinner, J. D. (1967) Puberty in the male rabbit. F. Reprod. Fert. 14, 151.

Sterlman, S. L. \& Pohley, Florence M. (1953) Assay of the follicle stimulating hormone based on the augmentation with human chorionic gonadotrophin. Endocrinology, 53, 604.

Threadgold, L. T. (1957) Sudan black and osmic acid as staining agents for testicular interstitial cells. Stain. Technol. 32, 267.

Watson, R. H., Sapspord, G. S. \& MaCance, I. (1956) The development of the testis, epididymis and penis in the young Merino ram. Aust. F. agric. Res. 7, 574. 